\title{
我が国の排他的経済水域における 海洋再生可能エネルギーの展開に関する予備的考察
}

\author{
正員高 木 健 ${ }^{*}$ 正員大 澤 弘 敬 $^{* *}$ \\ A Preliminary Consideration on the Expansion of Ocean Renewable Energy in Japanese EEZ \\ by Ken Takagi、Member Hiroyuki Osawa、 Member
}

\begin{abstract}
Summary
Reduction of a $25 \%$ in greenhouse gas emission by 2020 is written in Japanese basic acts against global warming. Utilization of ocean renewable energy starts getting attention. A preliminary consideration on the expansion of ocean renewable energy utilization is shown in this paper. The obtained energy in a year per unit area for various ocean renewable energy devices is estimated. The required area is one of important indexes for evaluating the possibility of renewable energy devices. Other indexes such as the energy profit ratio, the cost and the typical weight of devices are also estimated, and the possibility on expansion of ocean energy utilization is discussed. Summarizing these results, it is found that J apanese exclusive economic zone has a considerable potential for ocean renewable energy. A closed system of an ocean renewable energy generation for the fishery industry in a remote island is proposed as for the first stage of deployment of the devices. In addition, further expansion of the ocean renewable energy utilization is discussed.
\end{abstract}

\section{1. 緒言}

地球温暖化対策基本法案では 2020 年までに二酸化炭素排 出量を $25 \%$ 削減を目指すことが書き込まれた。この政策実 現に向けて、政府は太陽光を始めとする再生可能エネルギー の支援に大きく舵を切ろうとしている．しかし、山がちの島 国である我が国では、陸上には再生可能エネルギー発電施設 の適地が限られており、海洋再生可能エネルギーへの期待が 高まっている。海洋再生可能エネルギーはこれまでにも、 様々な要素技術が研究され、個々の技術については経済性や エネルギー収支比（EPR）あるいはそのポテンシャルについ て議論されている。たとえば、植弘 ${ }^{1)}$ は洋上風力発電に関し て洋上展開に必要な面積や EPR について評価し、洋上風力 発電の可能性を論じている. 再生可能エネルギーはそのエネ ルギー密度が薄いため、発電装置を密集して配置することは できない.これは陸上面積の狭い我が国において海洋を利用 しようとする大きな理由の一つである.我が国の排他的経済 東京大学大学院

** (独) 海洋研究開発機構
水域（EEZ）は大変広大なので ${ }^{2)}$ 、面積的には我が国の 1 次 エネルギーを全て洋上で賄うことも可能かもしれない. しか し、単位面積当たりに得られるエネルギーが小さいとファー ムを組んだとしても、洋上で発電装置を支持するプラットフ オームのコストが掛かり過ぎ、経済的でなくなる，本報では 植弘のアイデアを他の海洋再生可能エネルギーにも拡張し、 様々な海洋再生可能エネルギーの展開に必要な面積を比較 した。さらに、経済性、エネルギ一収支比などを網羅的に検 討し直し、我が国の EEZ において、海洋再生可能エネルギ 一展開する際の指針を検討した。また、大規模展開に至るま での最初の段階として、地産地消型システムを提案し、そこ から大規模展開に至るまでの道のりについて考察した．

なお、本稿における議論で引用している EPR や発電単価 等は現実的な值とは考えられるが、現地におけるエネルギー 量の観測と発電装置の詳細設計・設置計画等が行われて初め て正確な值が求められる性質のものである.そのため、本稿 における考察は、海洋再生可能エネルギーを我が国 EEZ に 展開するうえで必要な予備的考察と位置付けた.

\section{2. 単位面積当たりのエネルギ一採取量}

我が国の場合、海洋再生可能エネルギーの最も重要な利点 として挙げられるのが、広大な排他的経済水域（EEZ）の有 
効利用である。これまでにも、個々のエネルギーについて EEZ を利用すれば大変大きなポテンシャルがあることが報 告されている.ここでは、このような評価法が適さないもの もあるが、エネルギーポテンシャルそのものではなく、一年 間に単位面積当たりに得られるエネルギーを概算し、Table 1 に比較してみる.概算の詳細はA ppendix A を参照されたい。

Table 10 btained energy in a year per unit area

\begin{tabular}{|c|c|c|}
\hline Technology & Electricity $\left(\mathrm{kW} \mathrm{h} / \mathrm{m}^{2}\right)$ & Oil $\left(\mathrm{kg} / \mathrm{m}^{2}\right)$ \\
\hline Solar PV & 140 & 11.5 \\
\hline Offshore Wind & 41 & 3.4 \\
\hline W ave & 8.5 & 0.7 \\
\hline Ocean Current & 51 & 4.2 \\
\hline Biomass & & $0.7 \sim 11$ \\
\hline
\end{tabular}

最後に参考のためバイオマスの例を挙げているが、バイオ マスは電力より、バイオディーゼルとして利用するべきであ るので、他の発電装置の值を熱量換算で石油換算值として掲 載した。また、バイオマスは、米国の研究例 ${ }^{3)}$ の值を用いた が、効率の高い微細藻類は淡水で生育するものが主であり、 洋上で育成できる種の值がどの程度になるのかは不明であ る.

これらの值を比較すると、単位面積当たりエネルギー量が 大きいのは太陽光エネルギーを直接変換している太陽光発 電とバイオマスであることが分かる. しかし、仮に売電価格 を¥25/kWh と高めに設定しても、20 年間で 1 平方メートル 当たり $¥ 70,000$ しか収入が得られない。したがって、これを 浮体式の基礎の上に設置する方式ではコストが掛かりすぎ ることが分かる。また、バイオマスの場合も販売価格を $¥ 200 / l$ と高めに設定しても、20 年間で 1 平方メートル当た り最大でも 39,600 にしかならい. したがって、海上に構 築する浮体施設は生筫のように安価にできるものでないと、 採算が合わない。一方、他の海洋再生可能エネルギーは 2 次元的に降り注いだ太陽光エネルギーが風、波、流れなどに 変換されて濃縮したエネルギーを、点で獲得しているので、 浮体施設のコストがかなり低く抑えられ、売電価格がある程 度以上であれば、十分採算が取れる。

Table 2 A rea for generating the total el ectricity of Japan

\begin{tabular}{|c|c|c|}
\hline Technology & A rea required $\left(\mathrm{km}^{2}\right)$ & Percentage \\
\hline Solar PV & 7,360 & 0.9 \\
\hline Offshore W ind & 25,100 & 3.1 \\
\hline W ave & 121,000 & 15.1 \\
\hline Ocean Current & 20,200 & 2.5 \\
\hline
\end{tabular}

単位面積当たりに得られるエネルギー量がおおまかに分 かったので、次に、仮に我が国の 2008 年の電力需要 $(1.03 \times$ $\left.10^{12} \mathrm{kWh}\right)$ をこれらの海洋再生可能エネルギーで賄った場合 に必要となる面積を計算してみた。さらに、その面積と我が 国の EEZ の内、水深が $1,000 \mathrm{~m}$ より浅い海域の面積 $(80.3$ 万 $\left.\mathrm{km}^{2}\right)^{2)}$ との比を求めた。 それらの結果をT Table 2 に緾める.

この表で分かるように、我が国の EEZ のごく一部を使う だけで、全電力需要量が賄えることがわかる。ただし、この 值を得るために用いた単位面積当たりのエネルギー獲得量 は比較的エネルギー獲得に向いた海域の值を用いているこ とや沿岸域、漁業がおこなわれている海域や航路などは避け なければならないので、実際にはこれほど大きな余裕は無い と考えられる．また、設置範囲を $1,000 \mathrm{~m}$ 以浅としているの で、この水深までの係留が低コストで実施できる技術を確立 しなければならない.

\section{3.エネルギ一収支比と経済性}

2 章において、我が国の EEZ は面積的には我が国の全電 力を賄えるだけの可能性があることが分かった. 次に一旦目 を個々の装置に転じて、個々の装置のエネルギー収支と経済 性について検討する.

\section{1 エネルギー収支比と発電コスト}

全てのエネルギーは製造・運用・その他、そのライフタイ ムに掛かる全エネルギーよりも獲得できるエネルギーが大 きくなければエネルギー装置としての意味が無くなる.また、 すでに地球上に存在するエネルギ一資源を利用してエネル ギーを得ている場合には、持続可能かという視点が必要にな る.ここで取り扱う海洋再生可能エネルギー装置は地球上に 降り注ぐ太陽光が他のエネルギー形態に変換されたものを 利用するだけなので、持続可能性の問題は少ないと考えられ るが、海流発電のように気候と密接に関連するエネルギーを 利用する場合はあまり大量のエネルギーは取得できないと 考えなければならない.

Table 3 Energy Profit Ratio by J acobsen ${ }^{4)}$ and by A mano $0^{5)}$

\begin{tabular}{|c|c|c|}
\hline Technology & Ref.4 & Ref.5 \\
\hline Solar PV & $4.2 \sim 12.9$ & 2.0 \\
\hline Wind & $33.1 \sim 87.5$ & 3.9 \\
\hline Wave & 11.3 & 1.9 \\
\hline Tidal & 14 & 2.5 \\
\hline Nuclear & $3.5 \sim 27.2$ & 17.4 \\
\hline Geothermal & $4.5 \sim 16.2$ & 6.8 \\
\hline Hydroelectric & $11.1 \sim 14.4$ & 15.3 \\
\hline
\end{tabular}

Table 3 に 2 つ文献に記載されているエネルギー収支比 （Energy Profit Ratio）を纏める．ただし、エネルギー収支比 は次式で定義される. 
エネルギー収支比 $=\frac{\text { 獲得した全エネルギー }}{\text { ライフタイル消費する全エネルギー }}$

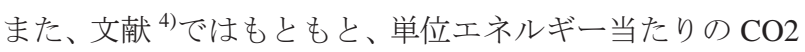
排出量が示されていたので、石油の然焼エネルギーとその時 排出されるCO2 の質量を用いて換算し、(1)式の定義で与え られるエネルギー収支比を計算した。両者を比較すると、水 力、地熱、原子力発電についてはほぼ同程度の值となってい るが、再生可能エネルギーに関しては、文献 ${ }^{4)} の$ 方が高い值 になっている。これは文献 ${ }^{5)}$ が最新の情報を使っていないた めか、両者でエネルギー装置の設置場所の考え方が違うため ではないかと推測される。

しかし、両文献ともに海洋再生可能エネルギー (風力は陸 上風力の值なので、洋上の場合はこれよりも下がる）はエネ ルギー収支比で 1 を遥かに超えており、エネルギーの観点か らは十分な収支が得られる。

なお、この 2 つ文献の比較から分かるように、最近この ような計算が各所で行われ、エネルギー収支比についても漸 くある程度の範囲に落ち着いてきているが、エネルギー装置 の設置場所や必要エネルギーの見積方等によってこの值は 変化するものであり、ある程度の幅があるということを念頭 に置くべきである.

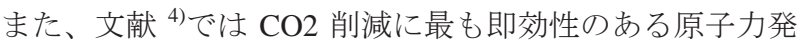
電に比べても海洋再生可能エネルギーが遜色ない值を示し ていることは注目すべきであろう。また、我が国で盛んにな りつつある太陽光発電よりも海洋再生可能エネルギーの方 が若干良い值となっている.特に風力発電はこの值が陸上の 值であることを割り引いてもかなり有望と考えられる

Table 4 E conomics of ocean renewable energy estimated by Suzuki ${ }^{6)}$

\begin{tabular}{|c|c|c|c|}
\hline Technology & $\begin{array}{c}\text { Facility } \\
\text { Cost }(¥ / \mathrm{kW})\end{array}$ & $\begin{array}{c}\text { Capacity } \\
\text { Factor (\%) }\end{array}$ & $\begin{array}{c}\text { Power } \\
\text { Price } \\
(¥ / \mathrm{kWh})\end{array}$ \\
\hline Offshore wind & 300,000 & 40 & $9 \sim 14$ \\
\hline W ave & 400,000 & 10 & 30 \\
\hline Ocean Current & 400,000 & $40 \sim 70$ & $7 \sim 14$ \\
\hline Onshore Wind & 250,000 & 30 & $9 \sim 14$ \\
\hline Nuclear & 300,000 & 80 & 6 \\
\hline Solar PV & 700,000 & 10 & 50 \\
\hline
\end{tabular}

次に Table 4 に鈴木 ${ }^{6)}$ による、再生可能エネルギーの発電 コストを示す. 発電コストの比較を行うと、原子力発電のコ ストが圧倒的に低いことが分かるが、太陽光発電に比べると 海洋再生可能エネルギーは遥かに低コストで原子力発電に
遜色ないものもあることが分かる.

\section{2 重量と出力の比}

このように、エネルギー収支や発電コストの面では大きな 問題点がないことが分かったので、次章ではコスト以外に海 洋再生可能エネルギーの抱える問題点とその解決法につい て論じる、その前に、発電コストのさらなる低減に最も重要 と考えられる発電装置の重量と発電電力量の比を検討して みる.Fig. 1 は実機が存在しているものやコンセプトが公表 されているものの中から、代表的な発電装置について、ホー ムページ等に記載されている概略寸法を用いて装置重量を 推定し、定格出力との比を描いたものである.

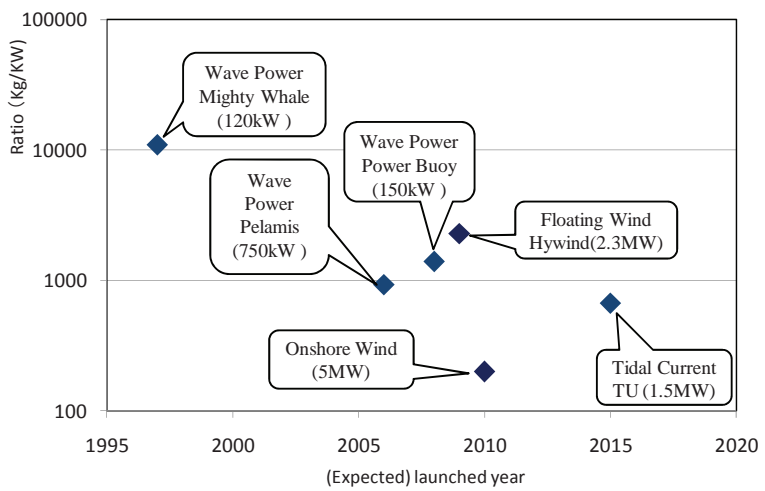

Fig. 1 W eight/Power ratio of ocean renewable energy devices

ここで、Mighty Whale $\mathrm{e}^{7)}$ は振動水柱式波力発電装置、 Peramis $^{8)}$ はターミネータ型波力発電装置、Power Buoy ${ }^{9)}$ はポ イント・アブソーバー型波力発電装置、StatoilHydoro ${ }^{10)}$ はス パー型洋上風力発電装置、TU (Tokyo University) ${ }^{11)}$ は浮体 式潮流発電装置である。なお、比較のために $5 \mathrm{M} \mathrm{W}$ 級陸上風 力の值も記載した。ただし、陸上風力発電装置 ${ }^{12}$ は基礎の 部分の重量が大きいのでここの值を推定しなければならな いが、簡単のために地上のポールと同じ重量を基礎部分の重 量と仮定した。また、陸上風車の場合は土地代の方が大きい 場合もあるので、ここでの比較にはなじまない可能性もある.

Fig.1の縦軸は定格出力 $1 \mathrm{~kW}$ 当たりの装置重量を対数軸で 示している。同じ波力発電でも第一世代に属する Mighty Whale は振動水柱型の空気タービンを用いているため、発電 効率が悪いことと、実海域試験で装置がダメージを受けるの を恐れたため、オーバースペックになっていることが崇り、 最近の波力発電装置に比べて一桁違うことが分かる.

これに対し、Pelamis やPower B uoy は波による装置の動き を直接油圧装置に接続して発電機を回転させるため効率が 良いことと、耐波性を重視した浮体形状により大幅な重量減 を達成している．また、Statoil のコンセプトも浮体式では最 も重量軽減が可能と考えられるスパー式を採用している. TU 潮流・海流発電装置のコンセプトは、メンテナンスが容 
易なように少し大きめの浮体を用いているため、重量が若干 大きくなっているが、密度の大きい海水で直接タービンを回 して発電する方式は大変効率が良いため、重量比でも有利な ことが分かる.さらに、洋上風力発電や潮流・海流発電は波 力発電や陸上風力発電に比べて一般的には設備利用率が高 いので実質的な発電コストでは有利である.

このような整理をしてみると、ヨーロッパで実用化が進み つつある海洋再生可能エネルギー装置の重量出力比が大凡 $1,000 \mathrm{~kg} / \mathrm{kW}$ であることから、今後我が国で開発されるであ ろう海洋再生可能エネルギー装置はこれより小さな值を目 標にしなければならない, その場合に問題となるのは我が国 では台風のような極限海象に対して設計值を決めなければ ならないため、どうしてもオーバースペックになり勝ちなこ とである。しかし、これを逆に利用し、我が国固有の極限海 象に耐えかつ低コストの装置を開発できれば、国際的な技術 的アドバンテージとなり、アジア地区での競争に有利になる とも考えられる.

一方、洋上風力発電や潮流・海流発電では風や海水の抗力 に対抗するため大きな係留力が必要なことが問題となる.特 に、潮流・海流発電は海水密度が大きいため、同じ出力でも 風力発電装置よりかなり大きなスラスト力を受けるため、係 留が難しく、ここのコストがかさむことが考えられる.また、 我が国 EEZ は水深が急に深くなるため、本稿の検討では全 てを浮体式と仮定して論じており、かつ水深 1,000m までは 技術的に可能としているが、実際の装置設置においては、前 述の係留系の問題と相まって大きなコスト増の要因をはら んでいる. 実際、鈴木 ${ }^{6}$ 莎算出したコストは多数の発電装置 をファームとして設置した場合の值であり、専用船を用いず に少数の装置を設置する場合の設置費をコストに上乗せす れば、発電コストが大変高いものになるのは間違いない.

しかし、我が国における陸上での大型風車設置では風況の 良い山岳地などに苦労して大型風車を運び上げるのに比べ ると、洋上設置は船上に載せた風車を現地まで運んで係留装 置とともにその場で船上から設置するだけであるから、洋上 の方が有利だといら考えもあり、設置やメンテナンス、ある いはそれらを実施する専用船の新コンセプトなどを含んだ 総合的エンジニアリング技術を高めれば、ここでのコストは それほど嵩まないとの楽観的見方も可能である.

\section{4. 海洋再生可能エネルギー装置の展開}

前章までの検討で、我が国の EEZ を利用すれば海洋再生 可能エネルギーには大きな可能性があり、多少の開発要素は あるものの、エネルギー収支比や発電コストの面でも従来型
の発電方式と遜色はないことが分かった，そこで、海洋再生 可能エネルギー装置の展開の障害となっている事項につい て考察を行ってみる.

一般的に再生可能エネルギーは出力変動が大きいため、そ の変動を平滑化するため、2 次電池と組み合わせて平滑化が 行われるが、長い周期の変動を平滑化するための 2 次電池を 装備すると大きな発電コストの増加を招いてしまう.最近で は大規模な電力網内の出力変動をコントロールして再生可 能エネルギー装置を系統連結可能にするスマートグリッド の開発が進んでいるが、出力変動の大きなものはなるべく系 統に接続しない方がよい. そのため、再生可能エネルギーに は地産地消が適していると言われてきた. 太陽光発電装置を 一般家庭の屋根に取り付け、発電出力を 2 次電池に蓄電する 方式はこの典型であり、我が国がまずこの方式に大きな支援 を開始したのは当然である.少し規模を大きくした再生可能 エネルギーの地産地消の社会実験も行われている ${ }^{13)}$.

高木ら ${ }^{14)}$ は海流発電を利用した離島・地域振興と水産業 安定化の提案を行っている.この提案では海流発電により電 力を発電し, その発電電力を利用して沖合養殖施設の自動給 餌施設や浮沈設備に電力供給を行う。また, 余剩電力は漁港 施設の照明・給水，・冷凍・冷蔵庫，製水等，あるいは漁村 集落の照明・通信，水産物加工などのための給水・動力源へ 優先的に低コストで供給する.

一方, 海流流速の変化に伴う供給電力の変動は, 短期のも のについては 2 次電池に貯蔵した電力で対応し, 長期にわた るものは既存の火力発電施設からの供給量を増加して対応 することが考えられる.また, 海流の流速と流向はコンピュ ータシミュレーションによって予測し, 電力の変動を事前に 知ることにより既存の発電システムとの協調を図る. Fig. 2 にこの提案システムの例を示す.

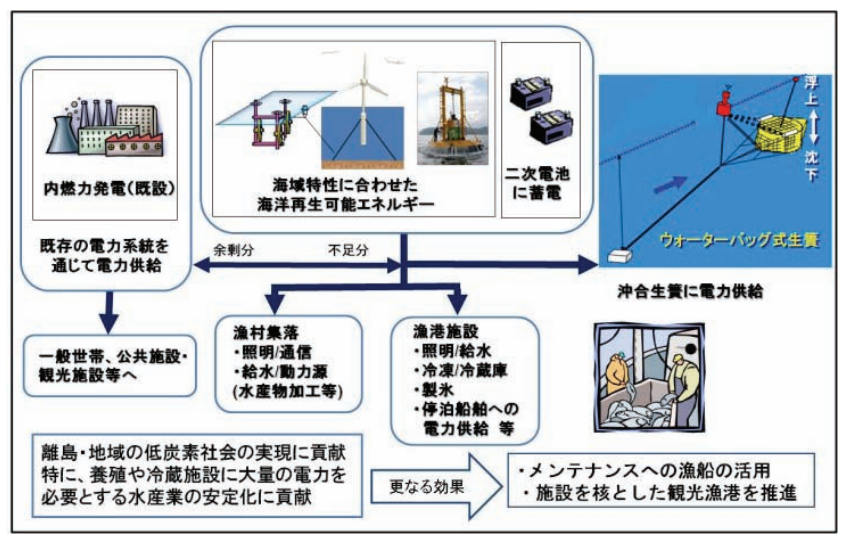

Fig. 2 Closed system of an ocean current generation for the fishery industry in a remote island. 
海洋再生可能エネルギーの商用化の第一段階ではこのよ うに地元の産業、特に水産業との協調を考慮した小規模クロ ーズドシステムから始め、海洋再生可能エネルギー発電装置 の信頼性向上や性能向上、また、変動電力の平滑化を含めた システム全体を離島や地域にマッチングさせる社会実験を 実施するのが無理なく導入するうえで良策であると考えら れる。

さらに、これらの小規模システムを徐々に発展させ、大規 模化させていくことになるが、その際には、ある程度の規模 を持ったファームとして計画する必要がある。 その理由は、 まず始めに装置の開発においては、ある程度のボリュームを 持った市場でないと、技術レベルの高い製造メーカが参入せ ず、技術のレベルアップが望めないことと、電力ケーブルや 敷設工事などに掛かるコストを抑えるためである.

ここで問題になるのは、ある程度の規模の発電を行うと、 離島での電力需要をすぐに越してしまうことである. そうな ると、余った電力を大消費地に送る必要が生じる. そのため には、海底ケーブルを敷設する必要が生じる。この場合も、 なるべく大規模なファームから、一本の海底ケーブルで電力 を送る方がコストを抑えることができる.このようなことが 実現されるのは相当先の話なので、その頃には、電力変動の 緩和に必要な各種インフラの整備も進んでいると考え、単純 に海底ケーブル敷設に必要な経費を考察してみる. 経費の導 出過程は A ppendix B に記す。これによると、三浦半島から 八丈島まで約 $240 \mathrm{~km}$ の海底ケーブルを引いた場合で $¥ 0.2 / \mathrm{kWh}$ （全電力の $2 \%$ 送電と仮定）、鹿児島から石垣島 まで約 $1100 \mathrm{~km}$ の海底ケーブルを引いた場合で¥0.95/kWh を 電力価格に追加するだけで良いという結果になった。

三浦半島から八丈島にかけての海域と鹿児島から石垣島 にかけての海域では洋上風力、波力、海流などの様々な可能 性がある.海域の特色にあった発電法を選んで大規模展開す れば、この程度のコストは問題でないので、海底ケーブルに よる電力輸送も視野に入るのではないかと考えられる.

なお、Appendix B に記したように、海底ケーブルの価格 は陸上ケーブルから推定したものなので、もっと高価になる かもしれない. 仮に価格が 5 倍だとすると三浦半島一八丈島 で¥1.0/kWh、石垣一鹿児島で $¥ 4.8 / \mathrm{kWh}$ の価格上乗せになる. また、送電ロスも考えられるので、石垣一鹿児島間は途中の 島で消費することや、石垣一台湾間の送電なども検討すべき である。

\section{5. 結 言}

海洋再生可能エネルギーの大規模利用の可能性について
調べるため、必要面積、電力価格、EPR、装置重量の観点か ら論じた。さらに、大規模利用に至るまでの展開法について も論じた。これらを䌂めると、技術的に超えなければならな いハードルはいくつもあるものの、我が国 EEZ は海洋再生 可能エネルギー利用に関する大きな可能性を秘めているこ とが分かった。また、今後の装置開発において最も重要と考 えられる重量出力比の開発目標を与えた.

水産業など離島や地域の産業に協調して海洋再生可能工 ネルギーを地産地消するクローズドシステムの提案を行っ た.このシステムを起点として排他的経済水域に大規模展開 する上で必要と考えられる海底ケーブルの可能性について も検討した，その結果、大電力海底ケーブル敷設費が陸上ケ ーブル敷設費と同程度のオーダーであれば、コスト的には大 きな問題でないことが分かった。

なお、海洋温度差エネルギーの利用については、我が国 EEZ 内では本土から遠く離れた海域を除いて、温度差が小 さく、発電としては効率が悪いため、比較の対象から省いた. ただ、海洋温度差エネルギーは深層水の冷熱利用など熱を直 接利用や深層水に豊富に含まれる栄養塩の利用などと複合 的に利用することにより価值が生ずるので、本稿における検 討とは異なる観点からの検討が必要である。

また、海洋再生可能エネルギー発電装置の装置設置による 環境影響は小規模なら影響は小さいと考えられているが、大 規模なファームが設置された場合の環境影響評価は今後の 課題である。

\section{謝辞}

本稿を緾めるにあたり、海洋技術フォーラム幹事会での議 論が大変参考になった.ここに幹事会各位に謝意を表わした い.

\section{参 考 文 献}

1) 植弘崇嗣: 洋上風力発電の展開とエネルギー収支、第 2 回洋上風力発電フォーラム講演集、2005, pp.9-18.

2) P. T. Pienkos and A. Darzins :The promise and challenges of microalgal-derived biofuels, Biofuels, Bioproducts and Biorefining. V ol.3, 2009, pp.431-440.

3) 福島朋彦：排他的経済水域の特徵と資源開発、第 25 回 海洋フォーラム、SOF 海洋政策研究所 2005.

4) M.Z. Jacobsen : Review of solutions to global warming, air pollution, and energy security, Energy and Environment Science, 2009, V 0.2, pp.148-173. 
5) 天野治: 石油の代替エネルギーをEPR から考える、(社) 日本原子力学会誌、Vol.48, No.10, 2006.

6) 鈴木英之: 洋上風力分野の動向と洋上風力分科会活動報 告、海洋エネルギー資源国際フォーラムテキスト、2009、 pp.38-51

7) JAMSTEC:波浪エネルギー利用技術の研究開発一沖合浮 体式波力装置「マイティーホエール」の開発一、2004.

8) Pelamis Wave Power Home Page, http://www.pelamiswave. com/

9) Ocean Power Technologies Home Page, http://www. oceanpowertechnologies.com/

10) Statoil Home Page, http:// www. statoil. com/ en/ Pages/ default. A spx

11) 鈴木英之、早稲田卓爾、大内一之：黒潮による海流発 電システムの基礎的検討一海流・潮流発電検討のために 一、日本船舶海洋工学会海洋工学研究会 - 海洋環境研究 会合同部会学会、2008.

12)（独）国立環境研究所：平成 16 年度洋上風力発電を利 用した水素製造技術開発委託業務報告書、2004.

13) 例えば、「八戸市 水の流れを電気で返すプロジェク 卜」https:// www. city. hachinohe. aomori.jp/ index. cfm/ $9,4602,65,208$, html

14) 高木 健、鈴木英之、和田時夫、中山一郎 : 海洋エネ ルギーを利用した新海洋食料資源生産システムの開発 に向けての提言、第 38 回海洋工学パネル、p64-69, 2009

15) (独)産業技術総合研究所太陽光発電研究センター： http://unit.aist.go.jp/rcpv/ci/about_pv/supplement/supplem ent_1.html

16)(独)海洋技術安全研究所：日本近海の波と風のデータ ベース、 http:// www. nmri. go.jp /wwjapan/ namikaze _main .html

17) 戒能一成：日本の地域間連系送電網の経済的分析、 RIETI Discussion Paper Series, 05-J-033

\section{Appendix A}

再生可能エネルギーの単位発電量当たり必要面積の出し 方について詳述する。

まず始めに、太陽光発電について述べる. 太陽からの光エ ネルギーは大気による反射や吸収により減少するが、ここで は、簡単のため我が国の太陽光エネルギーを計算する際に良 く用いられる $1 \mathrm{kWh} / \mathrm{m}^{2}$ を地上に到達するエネルギーとする。 太陽光発電装置の効率は将来有望とされる薄膜シリコンや
CIGS の最高効率とされる 15\%とし、設備利用率を $11 \%$ とし $た^{15)}$.

洋上風力発電は $5 \mathrm{M} \mathrm{W}$ 風車（風車直径 $D=120 \mathrm{~m} ）$ が前後に 10D、左右に3D 離れて設置されており、設備利用率が 44\% と仮定した。

波力発電はエネルギーが 2 次元的に伝播するため、必要面 積として表わすのが難しい，そこで、外洋においては統計的 にはほぼ同じ確率であらゆる方向から波が入射してくるこ とから、直径 $10 \mathrm{~km}$ の円内に周りから一様な波高の波が入射 するとして、円内に入射するパワーを計算した。また、波高 は（独）海上技術安全研究所の「日本近海の波と風のデータ

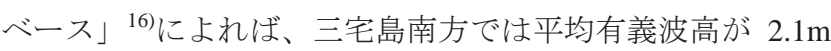
程度になっているので、波高 $2.1 \mathrm{~m}$ 、設備利用率 $30 \%$ として 計算した。

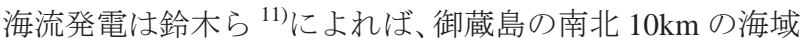
で水深 50m までの通過パワーが 580M W とされている。こ れは、平均流速 $1.3 \mathrm{~m}$ に相当する。海流発電は風力発電と同 等の扱いが可能と考えられるが、水深が深くなれば流速が低 下寸るので、風力発電の場合より前後方向の流速回復は遅く なると考え、前後 $15 D$ 、左右 $3 D$ の間隔とした。ただし、タ ービン直径は $48 \mathrm{~m}$ の $1 \mathrm{M} \mathrm{W}$ 機で設備利用率は $60 \%$ とした。

なお、海洋再生可能エネルギーの設備利用率は近年行われ ている研究の值を参考にして決めた值である.

\section{Appendix B}

海底ケーブルの価格推定について述べる.海底ケーブルは プロジェクト毎に価格が変動し、一般的な価格推定が大変困 難である.陸上の電力ケーブルについても同様のことが言え るが、戒能 ${ }^{17)}$ は 10GW （5GW2 回線）の高圧送電線の場合 $¥ 21 / \mathrm{km} / \mathrm{kW}$ と推定している. 仮に国内の総電力の $2 \%$ を送電 するとすれば、約 $2.3 \mathrm{GW}$ である。送電電力は最大值で考え なければならないので、簡単のため設備容量を $23 \%$ とすれ ば最大電力は $10 \mathrm{GW}$ となる。これに先ほどの值を用いると 2.1 億円 $/ \mathrm{km}$ となる. $240 \mathrm{~km}$ の海底ケーブルで利子率を $4 \%$ と して、15 年間運転すると¥0.2/kWh となる.

ただし、現在の技術では海底ケーブルは陸上より送電容量 の小さなものが使われており、この計算はそのまま成り立た ない可能性もある。しかし、陸上は土地代が高いのに対して 海底では土地代が掛からないことと、海底ケーブルを用いる のは相当先のことなので、海底ケーブルの複数同時敷設技術 の開発や高電圧海底ケーブルの開発などの可能性があるこ とから、この值はオーダー違いにはならないと考えられる。 